\title{
SYMPOSIUM ON LIMITATIONS OF THE BEHAVIORAL TURN IN INTERNATIONAL LAW
}

\section{BOILERPLATE IN INTERNATIONAL ECONOMIC LAW}

\author{
Lange Poulsen ${ }^{*}$ and Michael Waibel ${ }^{* *}$
}

Boilerplate treaty provisions are identical or nearly identical terms that reflect settled legal language in treaties with different states parties. They are often taken from model treaties or templates and reflect non-negotiated "default rules" or rules that emerged in international practice, rather than individually tailored provisions adapted to the circumstances of the specific contracting parties. Although widespread in international economic law, boilerplate provisions have not been subject to much scrutiny, unlike their distant cousins in contract law. This essay highlights drivers and functions of boilerplate in international economic law along with core expectations from rationalist and behavioral approaches. Boilerplate can provide efficient solutions to international economic problems, for instance by reducing contracting costs, and provide bargaining leverage in asymmetric negotiations. Yet boilerplate can also result in unintended and unwanted consequences, such as when drafters fail to carefully consider "default" provisions or have an excessive preference for the status quo.

\section{Functions of Boilerplate in International Economic Law}

Boilerplate provisions are a prominent and remarkable feature of international economic law. Trade agreements typically include provisions with little or no variation across treaties. By one account, more than one hundred free trade agreements (FTAs) have taken more than 80 percent of their language from prior treaties, with some chapters copy-pasting more than 90 percent of their content from prior treaties. ${ }^{1}$ Boilerplate is even more pronounced in the thousands of extant investment treaties ${ }^{2}$ and double taxation treaties. ${ }^{3}$ This is not altogether surprising. For

* Associate Professor at University College London, London, United Kingdom.

** Professor at University of Vienna, Vienna, Austria. We thank. Anne van Aaken, Tomer Broude and Harlan Cohen, and other workshop participants for comments and suggestions, and Peter Behyl for research assistance.

${ }^{1}$ Todd Allee \& Manfred Elsig, Are the Contents of International Treaties Copied and Pasted? Evidence from Preferential Trade Agreements, 63 INT'L STUD. Q. 603 (2019). See also Jean Morin et al., The Trade Regime as a Complex Adaptive System: Exploration and Exploitation of Environmental Norms in Trade Agreements, 20 J. Int'l Econ. L. 365 (2017).

${ }^{2}$ Wolfgang Alschner \& Dmitriy Skougarevskiy, Mapping the Universe of International Investment Agreements, 19 J. INT'L EcON. L. 561 (2016); Wolfgang Alschner, Locked-In Language: Historical Sociology and the Path Dependency of Investment Treaty Design, in EDwARD ELGAR RESEARCH Handbook on the Sociology of International Law (Moshe Hirsch \& Andrew Lang eds., 2018); Joost Pauwelyn, At the Edge of Chaos?: Foreign Investment Law as a Complex Adaptive System, How It Emerged and How It Can Be Reformed, 29 ICSID REv. 372 (2014); Michael Waibel, Fair and Equitable Treatment as Boilerplate, 30 Am. Rev. Int'L Arb. 85 (2019).

${ }^{3}$ Vincent Arel-Bundock \& Lisa Lechner, Decentralized Multilateralism and the International Tax Regime (2021) (Paper on file with authors). Sovereign bonds also contain much boilerplate, although they are not treaties governed by international law; see Stephen Choi \& G. Mitu Gulati, Innovation in Boilerplate Contracts: An Empirical Examination of Sovereign Bonds, 53 Emory L.J. 929 (2004); Mitu GUlati \& RoberT

(C) Lauge Poulsen and Michael Waibel 2021. This is an Open Access article, distributed under the terms of the Creative Commons 253 Attribution licence (http://creativecommons.org/licenses/by/4.0/), which permits unrestricted re-use, distribution, and reproduction in any medium, provided the original work is properly cited. 
although idiosyncratic tailoring of provisions may appear more optimal when each treaty is considered in isolation, boilerplate can be a rational choice for states_ or at least state officials—with respect to five treaty stages: initiation, design, negotiation, implementation, and interpretation.

First, politicians and officials often have a career incentive to initiate treaties as salient indicators of "success": particularly when relevant audiences see treaties as a way of promoting the welfare of important constituents (such as foreign investors) or signaling membership in a desirable social group (such as a particular geopolitical alignment). ${ }^{4}$ The availability of boilerplate could be important here, as it increases the expected speed of completing treaties (see below), which, in turn, could tilt incentives towards treaties where boilerplate is available and away from those requiring extensive innovation on treaty language. The incentive for "rule-taking" from boilerplate is particularly important for capacity constrained states that are poorly placed to develop idiosyncratic legal language. The flipside is that when policy-makers want to avoid being seen as rule-takers, boilerplate could have the opposite effect by preventing certain treaties from being initiated. We are not aware of empirical evidence testing these propositions, but they strike us as intuitively plausible.

Second, and relatedly, when a state prepares a new agreement, or set of agreements, boilerplate reduces design costs compared with drafting idiosyncratic provisions. This may be attractive to state officials for the reasons mentioned above or to drafters incentivized to be risk-averse and to take the path of least resistance. ${ }^{5}$ Boilerplate allows for considerable efficiency gains, for instance when drafting complex multi-issue agreements like FTAs, and can provide bargaining leverage in asymmetric negotiations by acting as a focal point and signaling non-negotiable terms. ${ }^{6}$ Most investment and tax treaties, for instance, have been based on model agreements, which in turn were designed largely around the Organization for Economic Cooperation and Development's (OECD) drafts. ${ }^{7}$ These models did not just reduce design costs across treaty networks but also acted as focal points when developing countries proposed alternative drafting. ${ }^{8}$

Third, and crucially, once a critical mass of other treaties have adopted the same language, boilerplate can reduce negotiation costs. This network effect makes it rational for powerful states to invest in drafting boilerplate language but can also be useful for weaker states seeking to rapidly expand their treaty network, as often seen during economic and political transitions. Many FTAs signed by post-communist states in the 1990s, for instance, took less than a year to finalize and often shared more than 90 percent of their language with other agreements. ${ }^{9}$ The rapid spread and convergence of investment and tax treaties during the 1990s was even more remarkable. During 1994 and 1995, for instance, Romania signed more than one investment treaty every month. This would never have been possible without boilerplate..$^{10}$ Notably, boilerplate can also offer opportunities for simultaneous

E. Scott, The Three and a Half Minute Transaction: Boilerplate and the Limts of Contract Design (2013); Lee C. Buchheit \& Jeremiah S. Pam, The Pari Passu Clause in Sovereign Debt Instruments, 53 Emory L.J. 869 (2004).

${ }^{4}$ Lauge N. Skovgaard Poulsen \& Emma Aisbett, Diplomats Want Treaties: Diplomatic Agendas and Perks in the Investment Regime, 7 J. InT'L Disp. SETTL. 72 (2016).

${ }^{5}$ Dennis C. Mueller, Public choice III 359 (2003) (with further references).

${ }^{6}$ Claire Peacock et al., Boilerplate in International Trade Agreements, 63 INT’L STUD. Q. 923, 925 (2019).

${ }^{7}$ On tax, see Dagan Tsilly, Tax Treaties as Network Product, 41 Brook. J. INT'L L. 1081 (2016); Arel-Bundock \& Lechner, supra note 3. In the case of investment, standard form arbitration provisions were also developed by the World Bank, TAYLOR ST. JoHN, THE RiSE OF Investor-State Arbitration: Politics, Laiv, and Unintended Consequences (2018).

${ }^{8}$ On investment, see Lauge Poulsen, Beyond Credible Commitments: (Investment) Treaties as Focal Points, 64 INT'L STUD. Q. 26 (2020). On tax, see Martin Hearson, Imposing Standards: The North-South Dimension to Global Tax Politics. (2021).

9 Allee \& Elsig, supra note 1, at 610.

${ }^{10}$ See Lauge N. Poulsen, Bounded Rationality and Economic Diplomacy: The Politics of Investment Treaties in Developing COUNTRIES (2015). 
modification across many treaties, as in the case of the OECD "Multilateral Instrument" applied to thousands of tax treaties. ${ }^{11}$

Fourth, after successful negotiations, boilerplate can reduce implementation costs. Once a boilerplate provision has been deemed compatible with domestic law, including constitutional law, it will need little or no attention when implementing future treaties. Securing political support can also be easier if domestic veto-players value alignment with international practice. There is also a flipside to this coin, however, as implementation problems with one boilerplate provision can open a Pandora's Box for other treaties. For instance, after the Court of Justice of the European Union found in 2018 that boilerplate language on investor-state arbitration in the Netherlands-Slovakia Bilateral Investment Treaty (BIT) was incompatible with EU law, ${ }^{12}$ the result was the termination of more than one hundred intra-EU BITs two years later. ${ }^{13}$

Finally, after treaty adoption, boilerplate language can reduce the uncertainty of interpretation. ${ }^{14}$ Provided that tribunals value prior interpretations, boilerplate helps generate clarity about the meaning of a provision over time, possibly even allowing it to become customary international law. Specifically, the boilerplate character of a provision might caution against reading much into the specific intent of the provision, and facilitate interpreting boilerplate as intentionally standardized. ${ }^{15}$ This produces a network effect, which can help states, firms, and other end-users of boilerplate provisions. It also provides an added incentive to use boilerplate in treaty drafting in the first place. In addition, boilerplate allows for efficiency gains when interpretation is undertaken by states themselves, as a single state interpretation of a boilerplate provision can apply across all its other treaties with similar language.

Rationalist models thereby provide multiple avenues to explore the drivers and functions of boilerplate in international economic law, both at the level of states and individual officials and politicians.

\section{Behavioral Boilerplate in International Economic Law}

In some cases, however, boilerplate may be better understood with insights from behavioral psychology and economics, whether as variants of rational choice theory that account for cognition costs or as bridges to constructivism and logics of appropriateness. ${ }^{16} \mathrm{On}$ this view, boilerplate can be the result of individually irrational behavior by officials and politicians, which in turn also invites us to more closely consider the pitfalls of boilerplate in international economic law and how to overcome them.

${ }^{11}$ Wolfgang Alschner, The OECD Multilateral Tax Instrument: A Model for Reforming the International Investment Regime?, 45 BROOK. J. INT'L L. (2019). Prior to this multilateral instrument, the content of tax treaties lagged behind the content of the OECD model. Renegotiations of tax treaties on average took seventeen years: Dirk M. Broekhujjsen, A Multilateral Tax Treaty: Designing an Instrument to Modernise INTERNATIONAL TAX LAW 28 (2017).

12 Case C-284/16, Slovak Republic v. Achmea, ECLI:EU:C:2018:158.

13 Agreement for the Termination of Bilateral Investment Treaties Between the Member States of the European Union, 2020 O.J. (L 169) 1.

${ }^{14}$ Marcel Kahan \& Michael Klausner, Standardization and Innovation in Corporate Contracting (or "The Economics of Boilerplate"), 83 VA. L. REv. 713 (1997); Robert B. Adieh, Between Mandate and Market: Contract Transition in the Shadow of the International Order, 53 EMORY L.J. 691 (2004). On investment treaties, see Santiago Montt, State Liability in Investment Treaty Arbitration: Global Constitutional and Administrative Law in the BIT Generation (2009).

${ }^{15}$ Henry E. Smith, Modularity in Contracts: Boilerplate and Information Flow, 104 U. Mich. L. Rev. 1175 (2006).

16 See generally Anne van Aaken, Behavioral International Law and Economics, 55 HARv. InT'L L.J. 421 (2014); Tomer Broude, Behavioral International Law, 163 U. PA. L. REv. (2015); POULSEN, supra note 10. 
Aggregating inferential biases to the level of collective actors—like states—requires significant assumptions. Yet, negotiators, firm managers, adjudicators, and other individuals relevant for international economic law are subject to the same cognition constraints and inferential biases as the rest of us, and this could be important when they approach boilerplate. Salience and status-quo biases, for instance, provide the micro-foundation for Simon's notion of satisficing, where actors search for "good enough" rather than optimal solutions. ${ }^{17}$ Equally, the pathdependency of boilerplate could result from excessive "anchoring" to the status-quo, even when interpretation and application of a boilerplate provision has proven inefficient. Particularly when boilerplate terms come with lowprobability but high-impact risks, actors are unlikely to fully internalize those risks in line with rationalist expectations and may often wait until they have been affected themselves. ${ }^{18}$

The risks of boilerplate are greater in some contexts than others. ${ }^{19}$ First of all, consider the interaction between information processing and incentives through motivated reasoning. ${ }^{20}$ This implies that actors with incentives that treaties be adopted - like some officials and litigators_-would be more likely to see boilerplate as welfare enhancing overall. Equally, whereas powerful states may have initially developed boilerplate language as bargaining leverage, officials may over time develop an attachment to this language and genuinely believe that it enhances global welfare. ${ }^{21}$ By extension, individual preferences against certain types of treaties or obligations-perhaps for political reasons - can make state officials more likely to seek and accept information that such treaties or obligations thereunder are generally harmful. Actors do not always appreciate that where they stand on boilerplate can depend on where they sit.

Second, the ability to critically assess boilerplate language depends on expertise and experience. This is important for states with capacity constraints, in particular, where officials are less likely to "know what to look for" when presented with boilerplate. Equally, in states with high degrees of administrative turn-over and rotation, officials are unable to develop the same degree of experience through learning and feedback, which in turn can obstruct understanding of the implications of boilerplate and its alternatives.

There is considerable evidence for these propositions in the investment regime, ${ }^{22}$ but there is scope for mistaken inferences about boilerplate in other areas of international economic law as well. For instance, appreciating the interaction between boilerplate language in one provision and other parts of a complex agreement, or other international legal regimes altogether, requires state officials to have access to a wide range of trade law expertise, which is not always available in developing countries. There could be pitfalls with implementation of boilerplate as well, as the risk of breach increases when the implications of "natural" or "obvious" treaty language are less salient. For instance, without expert advice, few officials will appreciate the possible bite of a fair and equitable treatment obligation..$^{23}$

\footnotetext{
${ }^{17}$ Herbert Simon, Administrative Behavior (1947).

18 Jean Galbraith, Treaty Options: Towards a Behavioral Understanding of Treaty Design, 53 VA. J. InT'L L. 309 (2013); Melvin Aron Eisenberg, The Limits of Cognition and the Limits of Contract, 47 STAN. L. REv. 211, 240-243 (1995); Tess Wilkinson-Ryan, A Psychological Account of Consent of Fine Print, 99 Iowa L. Rev. 179 (2013).

${ }^{19}$ The following two paragraphs build on POuLSEN, supra note 10, ch. 2.

20 See, e.g., Dan M. Kahan et al., Ideology or Situation Sense: An Experimental Investigation of Motivated Reasoning and Professional Judgment, 164 U. PA. L. Rev. 349 (2015).

21 See also Manfred Elsig \& Karolina Milewicz, The Politics of Treaty Signature: The Role of Diplomats and Ties That Bind, 22 INT. NEGOT. 521 (2017).

22 Poulsen, supra note 10.

23 See also Waibel, supra note 2.
} 


\section{Boilerplate and Rational Baselines}

There are considerable challenges in distinguishing between rational and behavioral accounts of boilerplate in international economic law. For just as it is always possible to reverse-engineer some rational interest that boilerplate serves, it is equally possible to match some behavioral heuristic ex post. Moreover, the observable implications of behavioral insights often overlap with those of rationalist models, at least when it comes to the design and adoption of boilerplate as an outcome. This is particularly the case when allowing for imperfect information-for instance in the context of vague provisions-but also in principal-agent settings where it is individually rational for an official to embrace boilerplate even when it is not rational for her government or state.

The good news is that this leaves open a new research agenda on the conditions under which we find boilerplate in international economic law, and the implications in different institutional environments. In some cases, careful micro-level work on how actors design and approach boilerplate in international economic law may make cognition constraints, like elephants in a living room, too much to ignore. ${ }^{24}$ But in other cases, standard rational baselines will be sufficient to understand the drivers of boilerplate treaty provisions and their effects on international economic cooperation and conflict.

24 Paraphrased from John Conlisk, Why Bounded Rationality?, 34 J. Econ. Liт. 669, 691 (1996). 